\title{
Social Order Learning Through Social Experiment
}

\author{
R. Effendi \\ Communications Department, Universitas Pendidikan Indonesia \\ Bandung, INDONESIA \\ reffendi09@gmail.com
}

\begin{abstract}
People's violations on social order regulations are have become a common phenomenon. As illustrations, traffic rules are violated every day, roads and sidewalks are shifted into a street vendor's booth or a parking lot. As can be seen from the foregoing violations of the public order, Indonesian society has a low public awareness. Then, how to increase the public awareness on this matters? The author along with students of the Communications Department have conducted a social experiment. What is meant by social experiment here is not a form of research method but it is a type of learning model. This social experiment was intended to raise public awareness in maintaining social order. There were three social experiments conducted with the following themes: Smoking Kid, Honey Bear, and $U$ Turn. First, Smoking Kid is a social experiment using the help of children actors to give warnings to adults who smoke in public places. Secondly, Honey Bear is a social experiment intended for a zoo visitor who keep feeding animals in spite of the prohibition. The final experiment is U-Turn social experiment. It is conducted in order to raise bikers or driver's awareness on obeying U-turn sign. The results of the social experiments show that: a) peoples were heedless of the distinct prohibitive signs and other visibel regulations. b). The violators are generally aware about the regulations, but they set the law at defiance. c). Time and distance efficiency have become the main motives for the violators. d). The absence of guilt or shame when they made mistakes. e). No social sanctions to cope with the ongoing violations. f). Police enforcements could not make the offenders learn their lesson. The society members tend to abide by the rules only if the authorities were on the spot and keep an eye on them.
\end{abstract}

Keywords: social order, social experiment, smoking kid, honey bear, $U$ turn

\section{INTRODUCTION}

Various rule violations committed by urban communities continues to happen every day. Traffic rules are violated every day, road and sidewalk are converted into a peddler booth or a parking lot. In some of Indonesian neighboring countries the authorities are not physically keep an eye open for everything in front of the public. However, the people there live orderly. On the contrary, in Indonesia there are numerous of authorities show themselves on the field, yet law and order still far from being realized. Relating to the phenomenon, This form of of social order disfunction could be used as learning materials in teaching social sciences (sociology, or social studies). This paper will describe how social sciences learning can contribute in incarnating a well ordered and regulated community.

\section{Social regulation and Social order}

In teaching the social order concept, the components of social integration and social regulation cannot be abandoned. The concept of social integration and social regulation was coined by a well-known sociologist; Emile Durkheim [1] in studying the phenomenon of suicide as a social fact. The authors adopt the concept to assess the existing social order in a society. If a person has a low level of attachment and sentiment toward their own community, then there will be a lack of social orders. This type of society members can be categorized as egoistic society. People in this category are usually not much involved in activities within their community because they feel there are no valued bond. They are care less about most thing that happened to their town, even their actions could be one of the cause of their city's downfall. This type of person only act as his/her wishes. They have lack of love to their own city.

Conversely, there are many community members who sacrifice their time and energy for the sake of their society. This type of action known as altruistic. Altruistic people usually contribute a lot and willing to serve their time for the good of their community. People who meet these criteria will not tally their sacrifices for reciprocal demands. He or she would be happy if his works are useful for many people. These amazing individuals are not easily found. It is almost like finding needles in haystack. In other words, they are a special group of people who hold their own noble ideals and willing to implement the ideals.

Next, there are people who belong anomie type. This type is a kind of person who has a low attachment to the rules other than his or her rules. They have no shame, even if there is, it is in a very low of responsibility level. Violating rules is like a common thing for them and they act as if they were doing nothing wrong. They simply believe that they are not guilty.

The last type is the fatalistic type. This type of person is often complaint mush against almost every conditions, criticism and negative thinking without any given solutions are their main attribute. People like this are much more demanding to the government because they felt that they had fulfill all of their obligations (such as paying taxes).

Often we only care about social order only if something bad just happened. We are temporary realized and improved ourself. Then we just make another same mistakes. Is that mean that we are apathy?. Apathy [2] towards various risks signify a lack of interest, indifference or attention especially on matters relating to the public interest. In this case the ignorance and apathy of the occurred social order in their society.

The ideal attribute for coping with social disorder is a transformative behaviour. People who are transformative toward public life are those who have an understanding of the social order. They have an attitude that is characterized by a willingness to change or improve any inappropriate conditions. People like this have no fear of the dangers and risks that will be caused. A transformative type of person is an ideal agent of change to bring back order to the society. They have the awareness to prevent, minimize, and convert any misdemeanor social order violations. 


\section{SOCIAL EXPERIMENT}

Social order is also taught as one of the topics in social studies. The learning process of this topic can be conducted by applying a social experiment. The following steps can be considered in applying the method:

\section{a) Recognizing the problem}

b) Describing the problem

c) Selecting an experimental plan

d) Creating a scenario for the experiment

e) Implementing the action

\section{f) Evaluating the results and the solutions}

There are three social order based activites described in this paper; 1)smoking kids experiment, , 2) honey bear, and 3) $\mathrm{U}$ Turn experiment. In the first experiment, in spite of the smoking prohibition in public places people still smoke. In this case, the experiment was conducted by talent (played by three kids) who pretended to borrow a lighter for smoking to a person who smoke in front of them. As a respond most of the smokers advised the children not to smoke. Ironically, they were explaining the dangerous of smoking while they are smoking. The smokers know that it is not appropriate to smoke in public places but they were just being ignorant.

The second experiment was carried out at the Bandung Zoo. In this experiment, the visitors were not allowed to feed the animals and actually they were aware about the prohibition for not giving food to the animals. However, they still feed the animals (in this case: honey bears) as if it was allowed. When some of students put a prohibitive sign in front of the cage, the visitors started to doubt and stop feeding the bears. However, when there were no students kept an eye on them, the visitors started to feed the bears again. They only obey the rules when someone watching on them.

The third experiment were conducted on a road where vehicles are prohibited for a U-turn. Despite the prohibitive sign, the road users, particularly motorbike riders, still breaking that rules.

a) peoples were heedless of the distinct prohibitive signs and other visible regulations. b). The violators are generally aware about the regulations, but they set the law at defiance. c). Time and distance efficiency have become the main motives for the violators. d). The absence of guilt or shame when they made mistakes. e). No social sanctions to cope with the ongoing violations. f). Police enforcements could not make the offenders learn their lesson. The society members tend to abide by the rules only if the authorities were on the spot and keep an eye on them.

One's social order awareness is related to the level of moral development. According to Kohlberg, moral development is divided into three levels: Preconvention, convention and postconvention [3]. The first stage of moral behavior is based on: a) heteronomous morality and b) instrumental and reciprocity. The second stage is based on: a) interpersonal expectations and b) social system and conscience. The third stage is based on: a) social contracts and b) justice. This model is known as a cognitive moral development model.
All of the types of social groups above are exists in our lives. Thereby it would be ideal if we are able to transform ourselves into a socially cared society with a collective consciousness. That kind of consciousness is not just about the quantity of the community members. It is more than that. The main concern is how to enforce the firmness of the law, law enforcement, and a comprehensive education.

\section{CONCLUSION}

Teaching social order concept becomes meaningful if taught by social experiment. The steps is as follow: recognizing the problem, describing the problem, selecting an experimental plan, creating a scenario for the experiment, implementing the action, and evaluating the results and the solutions.

\section{Reference}

[1] George Ritzer, Sociological Theory, Second Edition, Alfred Knoff,Inc, 1988, pp 78-82.

[2] Ulrich Beck, World at Risk. UK: Cambridge Polity Press, 2010, p 48

[3] Kama A Hakam, Pendidika n Nilai. Bandung. MKDU Press, 2000,p 74. 